\title{
PIERĀDĪŠANAS STANDARTS SPORTA ŠĶİRĒJTIESAS LIETĀS PAR ANTIDOPINGA NOTEIKUMU PĀRKĀPUMIEM UN PUBLISKĀ KĀRTİBA
}

\section{STANDARD OF PROOF IN COURT OF ARBITRATION FOR SPORT IN ANTIDOPING CASES AND ORDRE PUBLIC}

\author{
Mārtiņš Dambergs, $M g$. iur. ${ }^{1}$ \\ Latvijas Universitātes Juridiskās fakultātes \\ Starptautisko un Eiropas tiesību katedras doktorants
}

\section{Summary}

The article is devoted to the current problems regarding standard of proof in the Court of Arbitration for Sport (CAS) in antidoping cases. The article was inspired by the recent decision of Moscow City Court that denied the recognition of Court of Arbitration Award regarding A. Zubkov on basis of ordre public due to breach of presumption of innocence and lack of evidence regarding violation of antidoping rules by the athlete. The article explains the legal argumentation used by the International Olympic Committee's Disciplinary Commission and CAS in the appeals proceedings. The author analyses the standard of proof in antidoping cases in WADA Code and practice of CAS in the application of the standard and potential evolution necessary for the standard of proof in antidoping cases.

Atslēgvārdi: Sporta šķīrējtiesa, antidopings, pierādīšanas standarts, pietiekamas pārliecības standarts

Keywords: Court of Arbitration for Sport, anti-doping, standard of proof, standard of comfortable satisfaction

\section{Ievads}

Sporta šķīēejtiesa² lietā CAS 2017/A/5422, ievērojot Sporta šḳīrējtiesas noteikumu 47. pantu, apelācijas kārtībā izskatīja Krievijas Federācijas atlēta, bobslejista Aleksandra Zubkova (Александр Зубков) apelācijas sūdzību par Starptautiskās

1 Autors ir Starptautiskās Bobsleja un skeletona federācijas (IBSF) viceprezidents juridiskajos jautājumos. Rakstā paustais viedoklis ir autora personīgais viedoklis un nav uzskatāms par IBSF oficiālo viedokli.

2 Lai gan spēkā esošās Sporta likuma redakcijas $11 .^{2}$ panta trešajā daḷā tiek lietots jēdziens "Starptautiskā Sporta arbitrāžas tiesa”, autors izmanto Pasaules Antidopinga kodeksa tulkojumā (Pieejams: https://vvc.gov.lv/index.php?route=product/search\&search=antidopinga\&category_id=60\&sub_ category=true\&description=true) lietoto nosaukumu "Sporta šķīējtiesa”. 
Olimpiskās komitejas Disciplinārlietu komisijas (turpmāk - Disciplinārlietu komisija) 2017. gada 6. decembra lēmumu SML-028. Ar šo Disciplinārlietu komisijas lēmumu tika atzìta Krievijas atlēta vaina antidopinga noteikumu pārkāpumā, nosakot Soču ziemas olimpisko spēlu rezultātu anulēšanu, kā arī mūža diskvalifikāciju no ziemas olimpiskajām spēlēm. ${ }^{3}$ Sporta šḳīējtiesas nolēmums šajā lietā izpelnijās plašu rezonansi, jo tas bija viens no nolēmumiem saistībā ar antidopinga noteikumu pārkāpumiem, kas tika konstatēti Soču ziemas olimpisko spēḷu norises laikā 2014. gadā.

2018. gada 21. novembrī Maskavas pilsētas tiesa pieṇēma lēmumu lietā Nr. 3M-0459/2018, ${ }^{4}$ kas tika skatīta pēc Krievijas Federācijas bobsleja atlēta A. Zubkova pieteikuma par Sporta šķīējtiesas nolēmuma lietā CAS 2017/A/5422 atzīšanu un izpildi dal̦ā, ar kuru atzìts, ka atlēts ir piel̦āvis antidopinga noteikumu pārkāpumus, nosakot Krievijas Federācijas sportistu ekipāžu diskvalifikāciju bobsleja divnieku un četrinieku sacensībās Soču ziemas olimpiskajās spēlēs.

Izskatot pieteikumu, Maskavas pilsētas tiesa atzina, ka Sporta šḳīrējtiesas nolēmums lietā CAS 2017/A/5422 nav atzīstams un izpildāms Krievijas Federācijā, pamatojoties uz Krievijas Federācijas publisko kārtību. Maskavas pilsētas tiesa spriedumā norāda, ka pie Krievijas Federācijas publiskās kārtības pieder aizliegums veikt tādas darbības, kas aizskar konstitucionālās tiesības un privātpersonu pamatbrīīibas, tai skaitā pārkāpj nevainīguma prezumpciju. Atbilstoši Maskavas pilsētas tiesas norādēm jebkuras šaubas par apsūdzētā vainu jātulko par labu apsūdzētajam, tāpēc Sporta šķīrējtiesas nolēmums lietā CAS 2017/A/5422 nav atzīstams un izpildāms Krievijas Federācijā, jo A. Zubkova vaina par antidopinga noteikumu pārkāpumu apstiprināta tikai uz pieņēmumu pamata, pārkāpjot nevainīguma prezumpciju. Tomēr, kaut arī Krievijas Olimpiskā komiteja par šo Maskavas pilsētas tiesas nolēmumu iesniedza apelācijas sūdzību, ar 2019. gada 19. janvāra apelācijas instances tiesas nolēmumu Maskavas pilsētas tiesas lēmums atstāts negrozìts un stājies spēkā.

Šāda Krievijas Federācijas tiesas pieeja ir raisījusi plašas diskusijas par Sporta šḳīējtiesas piemēroto pierādīšanas standartu antidopinga noteikumu pārkāpumu lietās. Sporta šḳīējtiesas pieņemts nolēmums, tāpat kā jebkurš starptautiskas šḳīrējtiesas nolēmums, atbilstoši N̦ujorkas konvencijas par ārvalstu šḳīējtiesu nolēmumu atzǐšanu un izpildīšanu (turpmāk - N̦ujorkas konvencija) V panta otrās daḷas (b) punktam, nododot nolēmumu atzīšanai un izpildei N̦ujorkas konvencijas dalībvalsts tiesai, tiek vērtēts atbilstoši valsts publiskās kārtības noteikumiem. Tajā pašā laikā Krievijas Federācija nav vienīgā N̦ujorkas konvencijas dalībvalsts, kurā nevainīguma prezumpcija pastāv kā daḷa no valsts publiskās kārtības. Tāpēc būtiski noskaidrot, vai antidopinga pārkāpuma lietā ir pareizi atsaukties uz nepieciešamību ievērot nevainīguma prezumpciju.

3 Sk.: Starptautiskās Olimpiskās komitejas Disciplinārlietu komisijas 06.12.2017. lēmums SML-028, 49. lpp. Pieejams: https://stillmed.olympic.org/media/Document\%20Library/OlympicOrg/IOC/WhoWe-Are/Commissions/Disciplinary-Commission/2017/SML-028-Decision-Aleksandr-ZUBKOV.pdf [aplūkots 04.03.2018.].

4 Maskavas pilsētas tiesas 21.11.2018. nolēmums lietā Nr. 3M-0459/2018. Nav publiski pieejams. 


\section{Pierādīšanas īpatnības Sporta šķīējtiesas nolēmumā lietā CAS 2017/A/5422}

Sporta šḳīrējtiesa nolēmumā lietā CAS 2017/A/5422 vērtēja Disciplinārlietu komisijas 2017. gada 6. decembra lēmumā SML-028 izdarītos secinājumus. Disciplinārlietu komisija vērtēja lietā pastāvošos pierādījumus, tai skaitā profesora Ričarda H. Maklarena (Richard H. McLaren) ${ }^{5}$ 2016. gada 16. jūlija ziņojumu, ${ }^{6}$ kā arī citus netiešus pierādījumus, kas norādīja uz atlēta vainu antidopinga noteikumu pārkāpšanā. Atbilstoši Disciplinārlietu komisijas secinājumiem tā vērtēja faktus par konkrētā atlēta pārkāpumiem, tomēr atzina, ka, tiklīdz bija konstatēta visaptverošas krāpnieciskas sistēmas pastāvēšana, tas var tikt ņemts vērā, izvērtējot ar katru atlētu saistītos pierādījumus. ${ }^{7}$ Tomēr Disciplinārlietu komisija skaidri norādīja, ka lēmums netiek pien,emts kolektīva taisnīguma interešu vārdā. ${ }^{8}$ Vienlaikus Disciplinārlietu komisijas lēmumā tika norādīts, ka lietās par antidopinga noteikumu pārkāpumiem pierādījumu novērtēšana prasa, lai lēmumpieṇēmēja institūcija rūpīgi izvērtētu visus tās rīcībā esošos pierādījumus jeb elementus, sverot to nozīmību un nosakot, kā katrs elements iederas un sader ar citiem elementiem, līdzīgi kā liekot mozaīku. Pierādījumu vērtēšanas procesa beigās lēmumpieṇēmējai institūcijai jābūt pietiekami pārliecinātai par to, ka reālā situācija, ievērojot pieejamos pierādījumus, norāda uz pārkāpuma pastāvēšanas faktu. ${ }^{9}$

Apelācijas sūdzībā Sporta šḳīējtiesai uzmanība tika pievērsta tieši pierādījumu trūkumam par izdarīto antidopinga noteikumu pārkāpumu, uzsverot, ka nav iegūti tieši pierādijumi par konkrētā atlēta vainu antidopinga noteikumu pārkāpuma izdarīšanā.

Nen̦emot vērā apelācijas sūdzībā paustos iebildumus, Sporta š̌kīrējtiesa lietas CAS 2017/A/5422 nolēmumā Disciplinārlietu komisijas izmantoto pieeju atzina par pamatotu, norādot: noteikta veida pierādījumu trūkums nenozīmē, ka pārkāpums nav noticis. ${ }^{10}$ Sporta šḳīējtiesa tāpat atzinusi, ka starptautiski atzìtā cīṇa pret dopingu ir sabiedrības interesēs, tāpēc antidopinga organizācijām tiek piel̦auts izmantot pat tādus pierādījumus, kas iegūti, pārkāpjot sportistu cilvēktiesības. ${ }^{11}$ Nolēmumā tāpat norādīts, ka atbilstoši Starptautiskā Antidopinga kodeksa 3.2. punktā noteiktajam fakti par antidopinga noteikumu pārkāpuma konstatēšanu var tikt nodibināti ar jebkādiem pieejamiem līdzekḷiem. ${ }^{12}$ Šāda

${ }^{5}$ Profesors Ričards H. Maklarens ir tiesību zinātņu profesors Rietumu Universitātē (Western University) Kanādā, McLaren Global Sport Solution Inc. vadītājs, konsultants McKenzie Lake Lawyers juridiskajā birojā un pieredzes bagāts Sporta škīinējtiesas šḳīējtiesnesis.

${ }^{6}$ McLaren Independent Investigation Report - Part I. Pieejams: https://www.wada-ama.org/en/resources/doping-control-process/mclaren-independent-investigations-report-into-sochi-allegations [aplūkots 04.03.2018.].

7 Sk.: Starptautiskās Olimpiskās komitejas Disciplinārlietu komisijas 06.12.2017. lēmums SML-028, para. 102. Pieejams: https://stillmed.olympic.org/media/Document\%20Library/OlympicOrg/IOC/ Who-We-Are/Commissions/Disciplinary-Commission/2017/SML-028-Decision-Aleksandr-ZUBKOV.pdf [aplūkots 04.03.2018.].

8 Ibid., para. 100.

${ }^{9}$ Ibid., para. 115.

10 Sporta šḳīējtiesas 03.11.2014. nolēmums lietā CAS 2014/A/3625 Sivasspor Kulübü v. UEFA, 142. punkts.

11 Sporta šḳīējtiesas 31.05.2010. spriedums lietā CAS 2007/A/1396\&1402 World Anti-Doping Agency (WADA) and Union Cycliste Internationale (UCI) v. Alejandro Valverde \& Real Federacion Española de Cicilismo (RFEC), 71. punkts.

12 Sporta šḳīējtiesas 23.04.2018. nolēmums lietā CAS 2017/A/5422 Aleksandr Zubkov v. International Olympic Committee (IOC), 675. punkts. 
pieeja saskan ar Sporta šḳ̄irējtiesas praksē nodibināto, ka antidopinga noteikumu pārkāpumu var konstatēt ar tādiem netiešiem pierādīšanas līdzekḷiem kā vainas atzīšana, liecinieku liecības vai citi dokumentāri pierādījumi, kas norāda uz antidopinga noteikumu pārkāpuma pastāvēšanu. ${ }^{13}$ Tādējādi Sporta šķīējtiesa lietas CAS 2017/A/5422 nolēmumā Disciplinārlietu komisijas lēmumu SML-028 atstāja negrozìtu.

\section{Pierādī̌̌anas standarts Sporta šḳīējtiesas lietās par antidopinga noteikumu pārkāpumiem}

Atbilstoši Starptautiskā Antidopinga kodeksa 3.1. punktā noteiktajam pierādīšanas standarts antidopinga noteikumu pārkāpumu lietās ir antidopinga organizācijas konstatētā antidopinga noteikumu pārkāpuma atbilstība lēmējinstitūcijas pietiekamai pārliecināšanai (angḷu val. - comfortable satisfaction), n̦emot vērā apsūdzības nozīmīgumu. ${ }^{14}$ Šis standarts visos gadījumos ir stingrāks nekā tikai vainas iespējamības (angḷu val. - balance of probabilities) izvērtējums, tomēr neprasa, lai pastāvētu pierādījumi, kurus nevar saprātīgi apšaubīt (angḷu val. beyond reasonable doubt)..$^{15}$ Sporta šḳīējtiesas noteikumos pierādīšanas standarts antidopinga pārkāpuma lietās atsevišķi nav noteikts, tomēr Sporta šķīrējtiesa praksē atzinusi, ka pierādī̌sanas standarts, kas jāpārvar antidopinga organizācijām, ir augstāks nekā vainas iespējamība, bet zemāks nekā vainas pierādīšana krimināltiesībās. ${ }^{16}$

Pietiekamas pārliecināšanas standarts tiek plaši lietots Sporta šķīrējtiesas judikatūrā lietās par antidopinga noteikumu pārkāpumiem. Piemēram, Pehšteinas lietā ${ }^{17}$ Sporta šķīējtiesa norādīja, ka praksē pastāv vairākas lietas, kas ir izturējušas Šveices Federālās tiesas ${ }^{18}$ pārbaudi saistībā ar norādēm par antidopinga pārkāpumu lietu krimināltiesisko raksturu. Atbilstoši tiesas norādēm pierādījumu novērtēšanas procesā antidopinga pārkāpumu lietās nav pamatoti attiecināt krimināltiesībās pastāvošo pierādī̌̌anas standartu, ievērojot antidopinga pārkāpumu lietās pastāvošo attiecību privāttiesisko raksturu. ${ }^{19}$ Tāpat Sporta šķ̄iējtiesa norāda, ka pietiekamas pārliecināšanas standarts tiek piemērots kā piemērots pierādījumu novērtēšanas standarts disciplinārlietās pat tad, kad piemērojamie noteikumi pierādīšanas standartu tieši nenosaka vai nenosaka pietiekami skaidri. ${ }^{20}$

13 Sporta šḳīējtiesas 10.02.2006. nolēmums lietā CAS 2005/A/884 Tyler Hamilton V/USADA \& UCI, 48. punkts.

14 Starptautiskā Antidopinga kodeksa 3.1. punkts.

15 Ibid.

16 Sporta škīiējtiesas 31.05.2010. spriedums lietā CAS 2007/A/1396\&1402, World Anti-Doping Agency (WADA) and Union Cycliste Internationale (UCI) v. Alejandro Valverde \& Real Federacion Española de Cicilismo (RFEC), 53. punkts.

17 Sporta šḳīrējtiesas 25.11.2009. nolēmums lietā CAS 2009/A/1912 \& 1913, P. \& DESG v. ISU, 124. punkts.

18 Šveices tiesai ir jurisdikcija vērtēt Sporta škīīējtiesas kā Šveicē registrētas šḳīrējtiesas pieṇemto nolēmumu atbilstību taisnīga procesa un publiskās kārtības apsvērumiem atbilstoši Šveices Starptautisko privāttiesību likuma 176. un 190. pantam - autora piezīme.

19 Introduction to International and European Sports Law. Capita Selecta. In: Siekmann R. C. R. ASSER International Sports Law Series. T.M.C. Asser Press, 2012, p. 27; Zaksaite S., Radke H. The interaction of criminal and disciplinary law in doping related cases. International Sports Law Journal, June 2014, 14 (1-2), p. 117.

20 Sporta šḳīējtiesas 15.04.2010. spriedums lietā CAS 2009/A/1920, FK Pobeda, Aleksandar Zabrcanec, Nikolce Zdraveski v. UEFA, 85. punkts. 
Iepriekš minētais norāda, ka Sporta šķīēejtiesas nolēmumā lietā CAS 2017/A/5422 piemērotais pierādīšanas standarts ir pilnībā saderīgs ar Starptautiskā Antidopinga kodeksa 3.1. punktā un Sporta šķīrējtiesas praksē noteikto.

\section{Pierādī̌anas standarta adaptēšanas nepieciešamība}

Kaut arī Starptautiskā Antidopinga kodeksa 3.1. punktā un Sporta škīiējtiesas praksē ir piemērots pierādīšanas standarts, pastāv diskusija par attiecīgā piemērošanas standarta atbilstỉbu nevainīguma prezumpcijas principam, tā aktualizē nepieciešamību noteikt augstāku pierādīšanas standartu antidopinga pārkāpuma lietās un tuvināt to pierādīšanas standartam krimināltiesībās. Kā viens no argumentiem norādītas sankcijas, kas tiek piemērotas antidopinga pārkāpuma lietas izskatīšanas rezultātā, proti, atlētam tiek piemērota diskvalifikācija no tālākām sporta sacensībām, ievērojot pārkāpuma smagumu. Fakts, ka sankcijas pēc būtības nav vērstas uz restitūciju, bet tām piemìt drīzāk sodošs raksturs, šķietami norāda uz sankciju krimināltiesisko raksturu. ${ }^{21}$ Tomēr, kā norādīts Starptautiskās Antidopinga organizācijas saņemtajā juridiskajā atzinumā par Starptautiskā Antidopinga kodeksa 2015. gada redakciju, ko sastādījis bijušais Eiropas Cilvēktiesību tiesas prezidents Žans Pols Kosta (Jean-Paul Costa), ${ }^{22}$ ir vairākas pazīmes, kas norāda, ka sankcijas, kas atlētiem tiek piemērotas antidopinga noteikumu pārkāpuma gadījumā, nav krimināltiesiska rakstura, piemēram, sankciju piemērošanas rezultātā pret personu netiek uzsākta kriminālvajāšana, sankcijas nav saistītas ar brīvības atņemšanu, sankcijas nav piemērojamas pret sabiedrību kopumā, bet pret speciāliem subjektiem (atlētiem vai to pavadošajām personām), kas šādu atbildību uzṇēmušies, izsakot skaidru piekrišanu.

Tomēr antidopinga noteikumu pārkāpumu lietas, kas tika izskatītas par Soču ziemas olimpisko spẹlu laikā konstatētiem pārkāpumiem, ir atsākušas diskusijas par pietiekamas pārliecināšanas kā pierādīšanas standarta atbilstību sankcijām, kas tiek piemērotas olimpisko spẹlı atlētiem. Starptautiskās Kamaniņu sporta federācijas Disciplinārlietu komisija, izskatot lietu par sankciju piemērošanu diviem Krievijas Federācijas atlētiem, balstoties uz identiskiem netiešiem pierādījumiem kā Disciplinārlietu komisija lietā SML-028, nolēma sankcijas nepiemērot. Tas pamatots ar to, ka iespējamā sankcija ir atlēta mūža diskvalifikācija no olimpiskajām spēlēm - tas norāda, ka iespējamai pārliecībai par pārkāpuma izdarīšanu jābūt īpaši augstai, ${ }^{23}$ bet konkrētajā lietā tā netika iegūta. Faktiski Starptautiskās Kamaniṇu sporta federācijas Disciplinārlietu komisija izmantoja Starptautiskā Antidopinga kodeksa 3.1. punktā noteikto rīcības brīivibu tiesību piemērotājam, izvērtējot, kādi apstākḷi dod pietiekamu pārliecību par pārkāpuma esamību. Tas sakrīt ar līdzšinējo Sporta škīiējtiesas praksi, kur skaidrots, ka apsūdzības nozīmīguma izvērtējums nenorāda uz pierādī̌sanas standarta maiņu, bet, jo nopietnākas

${ }^{21}$ Zaksaite S., Radke H. 2014, p. 120.

${ }^{22}$ Costa J.-P. Legal opinion regarding the draft World Anti-Doping Code. 2013. Pieejams: https://www. wada-ama.org/en/what-we-do/legal/legal-opinions-and-articles-on-the-code [aplūkots 28.02.2019.].

${ }^{23}$ Starptautiskās Kamaniṇu sporta federācijas Disciplinārlietu komisijas 02.01.2018. lēmums A. Demčenko un T. Ivanovas lietā (nav publicēts); atsauce Sporta šķīiējtiesas 23.04.2018. nolēmumā lietā CAS 2017/A/5422 Aleksandr Zubkov v. International Olympic Committee (IOC), 84. punkts. 
ir izvirzītās apsūdzības, jo pārliecinošākiem jābūt lietā esošajiem pierādījumiem. ${ }^{24}$ Šāda pieeja ir bijusi nozīmīga antidopinga noteikumu pārkāpumu lietās, jo nereti tiesību piemērotājam nav pieejami tieši pierādījumi, kas norāda uz antidopinga noteikumu pārkāpumu. Nosakot ievērojami augstāku pierādīšanas standartu (piemēram, pierādī̌ana ārpus saprātīgām šaubām), kā tas noteikts krimināltiesībās, antidopinga organizācijām situācijās, kad antidopinga noteikumu pārkāpumi iniciēti, organizēti un īstenoti valstiskā līmenī, būtu gandrīz neiespējami pierādìt pārkāpuma esamību pierādījumu neesamības dēḷ.

Tajā pašā laikā autors uzskata, ka pašreizējais pietiekamas pārliecināšanas standarts rada iespēju spekulācijām par pierādījumu pietiekamību un piel̦aujamību, tādējādi apdraudot Sporta šķīèjtiesas spriedumu autoritāti. Autora ieskatā Sporta škīiējtiesas praksē pastāvošās norādes uz pietiekamas pārliecināšanas standarta piemērošanu (jo nopietnākas izvirzītās apsūdzības - jo pārliecinošākiem jābūt pierādījumiem) neatvieglo šķīrējtiesneša uzdevumu pierādījumu izvērtēšanas procesā. Jebkurš antidopinga noteikumu pārkāpums, ņemot vērā, ka tiek izvērtēta individuāla atlēta atbildība par pārkāpuma izdarīšanu, ir vienlīdz smags. Tādējādi pietiekamas pārliecināšanas standarta piemērošana valstiska līmeṇa antidopinga noteikumu pārkāpuma organizēšanas gadījumā vai individuāla antidopinga noteikumu pārkāpuma situācijā neatš̌kiras - tiesību piemērotājam pēc iekšèjās pārliecības jānovērtē visi un jebkādi tam pieejamie pierādījumi, lai iegūtu pārliecību par pārkāpuma izdarīšanas faktu. Ja pastāv aizdomas par valstiska līmeņa antidopinga noteikumu pārkāpuma organizēšanu, ne vienmēr antidopinga organizācijas pierādīšanas slogs palielinās. Tomēr pietiekamas pārliecināšanas standarts ir saistīts ar tiesību piemērotāja subjektivitāti, nenosakot papildu apsvērumus, kas būtu jāṇem vērā, lai konstatētu iespējamu pārkāpumu.

Autors uzskata, ka antidopinga pārkāpumu lietās pierādīšanas standarts būtu papildus sasaistāms ar nepieciešamību pierādījumus novērtēt atbilstoši tiesiskai apziņai, kas balstīta uz loǵikas likumiem, zinātnes atzin̄ām un taisnības principiem. Ievērojot, ka Pasaules Antidopinga kodeksa mērḳis ir aizsargāt sportistu pamattiesības piedalīties sportā, kurā netiek lietots dopings, antidopinga pārkāpumu lietās pietiekamas pārliecināšanas standarts ir saistāms ne vien ar tiesību piemērotāja iekšèjo pārliecību par pārkāpuma izdarīšanas faktu, bet arī ar tiesisko apziņu, kas balstīta uz sporta integritātes aizsardzības interešu ievērošanu. Autora ieskatā šādas pieejas nostiprināšana Pasaules Antidopinga kodeksā atvieglotu antidopinga organizāciju iespējas, ievērojot loǵikas likumus un dedukcijas metodi, izmantot netieši attiecināmus pierādījumus, lai pierādītu antidopinga noteikumu pārkāpumu izdarīšanu. Vienlaikus šādu pierādījumu izmantošana nevarētu tikt atzìta par prettiesisku un neatbilstošu procesuālās kārtības noteikumiem, kas varētu būt par iemeslu nolēmuma neizpildī̌̌anai atbilstoši N̦ujorkas konvencijas V panta pirmās daļas (b) punktam.

Nobeigumā jāsecina, ka arī grozījumu izdarīšana Pasaules Antidopinga kodeksā attiecībā uz pierādī̌sanas standartu antidopinga noteikumu pārkāpumu lietās diez vai mainìtu Maskavas pilsētas tiesas nolēmumu lietā Nr. 3M-0459/2018, ievērojot, ka tiesa novērtē šḳīējtiesas nolēmuma atbilstību valsts publiskajai kārtỉbai. Tomēr autors uzskata, ka pierādīšanas standarta adaptācijas rezultātā ir iespējams izslēgt saprātīgas šaubas par netiešu pierādīšanas līdzekḷu izmantošanas

${ }^{24}$ Sporta šḳīrējtiesas 08.12.2014. nolēmums lietā CAS 2014/A/3630, Dirk de Ridder v. International Sailing Federation (ISAF), 115. punkts. 
piel̦aujamību antidopinga noteikumu pārkāpuma lietās saistībā ar valstiska līmeṇa antidopinga noteikumu pārkāpumiem.

\section{Kopsavilkums}

1. Sporta šķīrējtiesa antidopinga pārkāpumu lietās piemēro Pasaules Antidopinga kodeksa 3.1. punktā noteikto pierādī̌̌anas standartu - pietiekama pārliecināšana (comfortable satisfaction) ir stingrāks pierādī̌anas standarts nekā tikai vainojamības iespējamības (balance of probabilities) izvērtējums, tomēr neprasa, lai pastāvētu pierādījumi, kurus nevar saprātīgi apšaubìt (beyond reasonable doubt). Šis pierādī̌̌anas standarts tiek piemērots arī disciplinārlietās un sporta spēlu sarunāšanas (angḷu val. - match fixing) lietās.

2. Pietiekamas pārliecināšanas standarts ir piemērots pierādīšanas standarts antidopinga noteikumu pārkāpumu lietās, jo nereti tiesību piemērotājam (antidopinga organizācijai) nav pieejami tieši tādi pierādījumi, kas nepārprotami norāda uz antidopinga noteikumu pārkāpumu. Pasaules Antidopinga kodeksa 3.1. punkts dod plašu rīcības brīvību šì pierādīšanas standarta piemērošanā, ievērojot iespējamā pārkāpuma smagumu.

3. Tā kā antidopinga noteikumu pārkāpuma gadījumā tiek izvērtēta individuāla atlēta atbildība par pārkāpuma izdarīšanu, pietiekamas pārliecināšanas standarta piemērošana valstiska līmeņa antidopinga noteikumu pārkāpuma organizēšanas gadījumā vai individuāla antidopinga noteikumu pārkāpuma situācijā neatšķiras, ņemot vērā iespējamo pārkāpuma smagumu.

4. Lai nostiprinātu iespēju izmantot netiešus pierādijjumus lietā, it īpaši pastāvot pierādijumiem par valstiska līmeņa antidopinga noteikumu pārkāpumu organizēšanu, papildus subjektīvai pārliecībai nosakāma nepieciešamība pierādījumus izvērtēt atbilstoši tiesiskai apziņai, kas balstīta uz logikas likumiem, zinātnes atziṇām un taisnības principiem. Šādas pieejas nostiprināšana Pasaules Antidopinga kodeksā atvieglotu antidopinga organizāciju iespējas, ievērojot logiikas likumus un dedukcijas metodi, izmantot netieši attiecināmus pierādījumus, lai pierādītu antidopinga noteikumu pārkāpumu izdarīšanu, nemainot pierādī̌sanas standartu pēc būtības. 